\title{
STRUCTURAL FACTORS FOR A THIRD-GENERATION PORT: BETWEEN HINTERLAND REGENERATION AND SMART TOWN IN GIOIA TAURO, ITALY
}

\author{
FRANCESCO RUSSO, PAOLA PANUCCIO \& CORRADO RINDONE \\ Dipartimento di ingegneria dell'Informazione, delle Infrastrutture e dell'Energia Sostenibile, \\ Università degli Studi Mediterranea di Reggio Calabria, Italy
}

\begin{abstract}
The nodes of the TEN-T network are characterized by being reference places within the territories. High-speed stations, airports and international ports are increasingly becoming places of trade and therefore of added value production. In this sense, in addition to the primary functions for which they were born, they tend to assume others. The full development of a third-generation port implies the creation of some basic services that allow the port and the industrial areas closely connected to fully develop the port activities and logistics related to them. The port must maintain the characteristics of a highly productive system, but at the same time, the population of hinterland centers has to participate in the growth of the port, without inducing constraints on the activities of the port but, on the contrary, constituting residential rules areas with evolved characteristics. In other words, the port must be an opportunity for integrated development of the hinterland. By defining the area of direct integration, it is necessary to using some guiding international principles: from one side the port needs to have a service district and a residential pole that can share with hinterland municipalities; from the other side the actual urban sprawl can be modified regenerating the urban spaces of all nearby centers, and integrating the regenerated centers, according to the principles of smart cities. In the note, after the analysis of the development guidelines carried out at the international level, some nodes of the Italian transport core network TEN-T are recalled, that are characterized by being born as places exclusively aimed at transport activities. On this basis, the paper, referring to the real case of Gioia Tauro port, analyses the contribution that the territory can make for the full construction of a third-generation port. Keywords: third port generation, smart city, new town, urban regeneration.
\end{abstract}

\section{INTRODUCTION}

UNCTAD (United Nations Conference on Trade and Development) introduced in 1994, and then further developed, the concept of port generation [1]. It is possible to use synthetic definitions, developed in the international literature [2]-[4] that allow the three-port generations to be effectively identified.

The first generation concerns of all ports that sink their birth in past centuries, until the 19 th century. It is the ports that are born together with the cities. Indeed, they constitute the very element that allows the city to be realized. Starting with the city-ports of the Phoenicians, which allowed cities to obtain supplies and to sell their productions to other cities [5]. It can be assumed that the port-city relationship remains unchanged over the centuries, even with the birth of land transport systems: with the Romans the roads and with the industrial revolution ( 20 centuries later) the railways.

The second generation of ports leaves in the second part of the 20th century. The realization of large industrial settlements requires large transport capacities and the elimination of constraints of dimensions proper to terrestrial systems. Large industrial sites need to interconnect without constraints. Petrochemicals, steelworks and power stations are developing. Together with the industrial plants, a new generation of ships is born: tankers, suitable for the transfer of large quantities of goods in the liquid or gaseous state. These ships need different port physical characteristics: large, deep and specialized docks, particularly 
advanced in safety facilities. Large industrial plants and ships of new characteristics give birth to the second generation of ports.

The third generation of ports was born with the container revolution. In the last two decades of the 20th century, the container has been established as the main tool for the transport of goods, both intermediate and finished, between productions and consumers. The container is the instrument that allows the globalization of the economy. The affirmation of the united container (TEU), requires the birth of ships suitable for the transfer of containers. The first ships can transfer up to 1,000 containers and are readapted ships for this function. Immediately afterwards, however, the ships suitable for containers and therefore hyperspecialized are born. The size of these ships continues to grow to today's ships, which are capable of carrying more than 22,000 containers. The first- and second-generation ports are not suitable for these ships and are not equipped with areas for handling millions of containers. Third generation ports are born with deep docks, gantry cranes, large squares parking, intermodal equipment, spaces of service. The simplification of freight transport given by the container also changes the operation of factories itself. The historic industrial plant, where raw materials entered and finished products came out, is replaced by the modern plant that operates on some production parts and is deeply integrated with other factories that can also be found on other continents.

The third-generation port, leaving from the only transhipment function [6], [7], becomes the privileged place of passage not only of raw materials and finished products but also of all intermediate productions. Some processes are moved to plants built-in port areas. The port then becomes the strategic logistics base and the place of intermediate and/or final processing, assuming new functions [8]-[10]. Third generation ports are important production systems with a considerable presence of workers in relation to the port's ability to produce: general external logistics for all goods and specific logistics for production segments.

The issues that the paper addresses are closely interlinked, concerning the proposals that must be put at the basis of strategic planning of territory in a region lagging in development where insists a big transport node, and the possibility of integrating urban areas into a major transport hub, applying the made proposals.

To solve the issues, Section 2 describes territorial objectives and the proposed planning methodology; Section 3 examines the port and city limits referring to international answers; Section 4 illustrates the strategic directions to be followed in order to move from theoretical hypotheses to territorial implementation in Gioia Tauro port.

\section{TERRITORIAL OBJECTIVES AND PLANNING METHODOLOGIES}

The focused theme is particularly important because there are worldwide cases of large transport nodes created ex-novo that are completely unresolved in terms of the relationship with the territory: high-speed rail stations, airports, intercontinental ports.

This is the problem related to TEN-T core nodes at European levels to which the Gioia Tauro port belongs.

\subsection{Port and territorial objectives}

In the current conditions, from one side, there is a large port that produces only transport actions without further added value on the transiting goods. This results from the lack of services and adequate industrial areas. On the other hand, there is an urban area in serious crisis with a high rate of unemployment and a lack of adequate services that suffer from a disruptive sprawl. 
The development of a third-generation port implies the creation of basic services that allow the port and the closely connected industrial areas to fully develop port operations and logistics production and then the added value (AV). In literature, AV is the measure of the increase in value that occurs in the production and distribution of final goods and services thanks to the intervention of production factors. Then the general objectives are:

- develop port's activities that could increase the AV for goods (port's objective), noting the absence of a service center;

- develop the around territory (territorial objectives):

- to create the conditions for transferring the generated AV in the same territory; and

- to solve the separation between the port and urban area for contributing to this AV's transfer.

These objectives are connected to the one presented by the authors [11]. The focus of this paper is on territorial objectives.

There is a need to create an efficient service center, and, at the same time, it is necessary to integrate the neighboring population in the development of the port, without inducing constraints on the activities of the port. In other words, the port must be an opportunity for integrated development of the hinterland.

\subsection{Planning methodology}

For pursuing the territorial objectives, it is possible to implement a planning methodology articulated in different steps: individuate the problems; review the international experiences and theories to approach the problems; solve the problems, leaving from the international experiences. The work proceeds following the approach proposed by [12], from the realities to the theories, and from theoretical hypotheses to plan processes (Fig. 1).

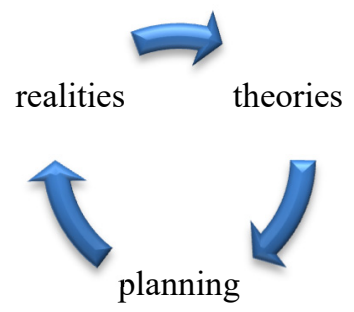

Figure 1: The adopted approach.

The analysis has two aims: to draw from reality the elements of synthesis to advance in the development of theoretical hypotheses; to find the appropriate tools to translate theoretical hypotheses into planning tools.

The general methodology can be implemented to the port and near territory.

The current problems to the port and the territory are: the lack of a business center, or specialized areas, where there is a concentration of services activities (e.g. tertiary, financial commercial); the urban sprawl that consumes territory and the decay of urban centers; the great presence of emerging technologies in the port and the absence of new technologies in the urban centers. 
The theories derived from international experiences must be then examined and the synthesis are presented in Section 3. In the last step, the theories are translated into planning proposals. Then the implemented methodology in terms of current and planned scenarios are schematized in Fig. 2.

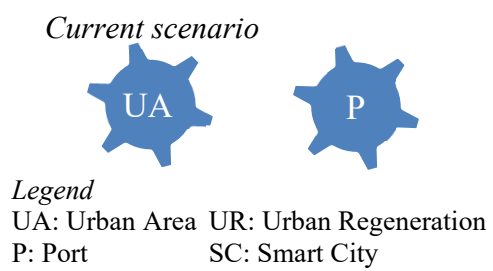

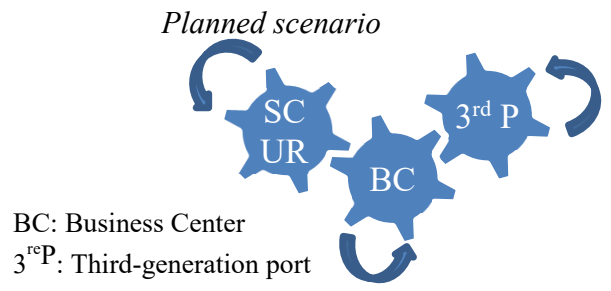

Figure 2: The methodology from current to planned scenario.

The current scenario has two separated entities, from one side the urban areas and from the other the port, each with specific problems.

The planned scenario solves the individuated territorial problems (through the theories) with the following interventions:

- development of ICT, energy and transport interconnections, towards a smart city model;

- urban regeneration of the current towns;

- an integrated residential area, towards a new town model, where it is possible to activate interactions among people, infrastructures and good's flows, the new area must stop the sprawl, giving to the employees a unified residential area; and

- realizing of a district center integrated with the new residential area.

\section{FROM PROBLEMS TO INTERNATIONAL ANSWERS}

\subsection{Strategic development of core transport node area}

Territories are an expression of the changes induced by economic, technological, historicalcultural and social developments. Urban planning theory assigns a generation plan to each historical period [13]. Building areas and large infrastructural works play a decisive role in determining these periods. In recent years, exemplary railway stations have been built in Italy, remarkable signs of innovation. These infrastructures, designed by international architects, indicate a further historical period in which the need for modernization converges with functional and technological innovation. However, it was found that these core transport node areas have their dynamics and do not integrate with the surrounding territory. Some references are the new stations of the Italian high-speed railway network: Mediopadana in Reggio Emilia and Napoli Afragola in Campania.

The territories are also characterized by phenomena that, in contrast to planning, assign spontaneous destinations in which the concentration of aggregative function is high. These dynamics are the reason why the territory often eludes the norm of the plans: the urban planning tools are unable to keep pace with innovation.

Important transformations occur due to practices decided by habitual behavior and organizational convenience. An example is the case of the Lamezia Terme railway station. The station has become a strategic hub of interchange and relationship for outsiders; vice 
versa, this place remains foreign to the Lametine citizen who recognizes the central square as the representative identity place.

\subsection{Territorial problems and theoretical solutions}

The uncontrolled expansion of the city, with respect to the rural areas, has transformed the open space in built spaces [14]. The current urban planning problem is sprawl. There is a widespread of buildings in territories, without the rule of the urban plan. The European Environment Agency [15] defines the urban sprawl as a low-density, sparse and extensive physical expansion model. It is characterized by empty spaces and low density that affect inefficient development.

The sprawl characterizes the current asset of the territorial area near the port of Gioia Tauro (Fig. 3), which comprehends directly the three towns inside the core area, the other 9 towns in the first circle and 21 in the second circle. The evolution of these territories often derives from spontaneous processes, activated to solve individual needs, without planning vision regulating by urban planning rules.

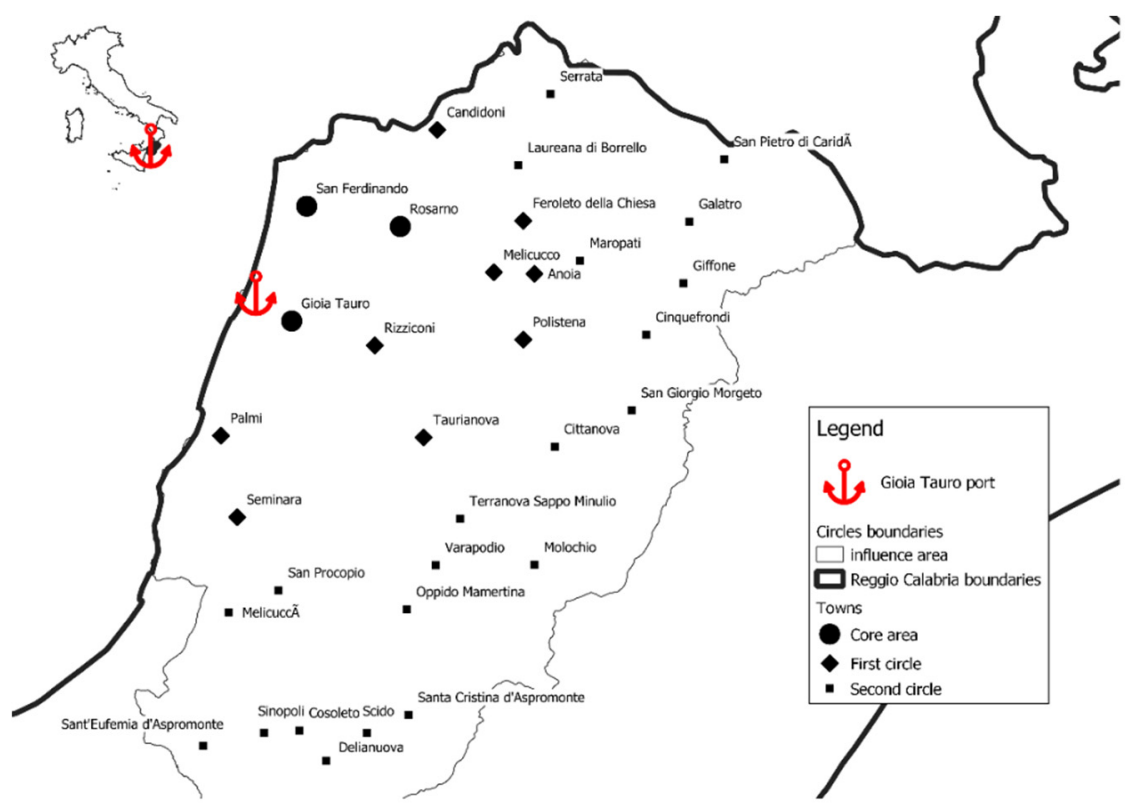

Figure 3: The influence area of the Gioia Tauro port.

The territory consists of widespread urban centers in the rural areas, which confronted with the intercontinental reality of the port of Gioia Tauro, belonging to TEN-T core network. The following problems are observed:

1. The three towns (Gioia Tauro, Rosarno and San Ferdinando) of the core area are not integrated and even less the other towns of the first and second circles. A residential development proceeds in an arbitrary way, the surfaces of urban areas increase without aggregation;

2. The area afferent the intercontinental port, has no services and business centers; and 
3. The integration between urban areas and the port requires advanced technologies supporting urban management, like the smart city approach.

One opportunity would be to regenerate these territories using planning, a link between knowledge and action, in an interconnected strategic process [16]. An urban regeneration project converts urban spaces into places of development, both to maximize the range of services and technological innovation and then increase the quality of life and well-being of citizens. The revitalization plans become necessary tools for the cities rebalancing; the urban spaces are relationship's places where mixed functions and differentiated social interests are organized [17]. The current hope of obtaining urban quality is the creation of spaces that are themselves producers and incubators of economic, social and environmental resources. The minimum landscapes and urban spaces are areas for experiment quality of life, with a specific focus on the new urban issues [18]. New places are proposed in which to incrementally rebuild the public dimension of the city [19]. Policymakers and planners have to promote and implement current ideas that facilitate transition cities towards health and resilience [20].

Literature has often focused on the concept of urban innovation as an opportunity for renewal from a spatial point of view. Instead, it has experimented that physical space plus the concentration of knowledge systems constitute an intellectual service infrastructure that promotes interaction between people, facilitates the creation of knowledge and promotes the production of innovation [21]. The time we are living is increasingly characterized by changes that mark the transition from the modern period to that of the new innovation; the city is renewed and the smart city takes shape.

At the international level, some new towns experimented smart city projects. For instance, since 2010, some smart city projects are developed for Japan's new towns. Principal examples are Kashiwa-no-ha Smart City and Fujisawa Sustainable Smart Town. In particular, Kashiwa-no-ha, situated around the Campus Station and served by the Tsukuba Express, is planned in an area of 273-hectare, designated as a land readjustment project area for a planned population of 26,000 inhabitants [22]. New towns represent examples of urban growth in China [23]. For instance, smart city projects are developed in new towns located in the Pearl River Delta, which represent examples of smart eco-city development. The case is of great interest because in the Pearl Delta are located 3 big third-generation ports: Hong Kong, Shenzhen, Guangzhou (Canton). Involved policy actors exchange resources and best practices to implement institutional and organizational assets [24].

European Commission (EC) has introduced the smart city's concept promoting solutions that integrate energy, ICT and transport to contribute to sustainable development and quality of life at the urban level [25]. The European Innovation Partnership on Smart Cities and Communities (EIP-SCC) is the main marketplace supported by EC to design and implement smart city solutions. The EIP-SCC brings together public and private actors active in the field of smart cities. The European's partnership produced the Strategic Implementation Plan (SIP) and the Operational Implementation Plan (OIP) recommending for integrated planning and management to converge theories, rules and implementation [26].

"Action Cluster" assembles a subset of partners that face specific issues related to smart cities, sharing the knowledge and expertise. The EIP SCC groups smart cities' actions in six action clusters [27]. Based on the clusters, EC funded "Smart Cities Lighthouse projects" under the European Union's Horizon 2020 Research and Innovation Programme (H2020) in the field of energy, transport and ICT. The H2020 has offered opportunities to implement smart city solutions. Since 2014, a total of 17 lighthouse projects have involved 46 lighthouse cities and 77 fellow cities [28]. These cities are working on implementing technologies and business models to transform their urban areas into sustainable places. 


\subsection{Port problems and theoretical solutions}

UNCTAD [1], [29] defined three generations of ports, directing the disciplinary debate towards further definitions [2]. The 3rd generation port cannot do without the business center and the integrated territorial system.

In recent years, the evolved metropolises have assigned areas of their territory to the construction of business centers. These are specialized areas with a concentration of tertiary, commercial, financial and various services activities. They are often places formally recognizable by the presence of representative buildings, such as skyscrapers, designed by archistars. The idea is that these places must be easily identifiable and must have some welldefined urban characteristics, such as: good accessibility, proximity to transport infrastructures or interchange nodes, proximity to exchange flows, a significant supply of services, and substantial extension of available surface.

In Italy, the EUR is the precursor model of a business center, even if it was built for the Universal Exposition scheduled for 1942 [30], [31]. The Centro Direzionale di Napoli, completed in 1995, is a set of skyscrapers intended mainly for offices that form a compact citadel, designed by the architect Kenzo Tange.

Compared to the current state of urban dynamics, it can be hypothesized that regenerating places, allow the design of territorial contexts with high quality, both environmental and technological. This implies the application of the smart opportunities adopting advanced design methodologies and criteria to obtain new towns of the next generation: the new town can be a model of an integrated territorial system.

The New Towns Act of 1946 started the new towns around London, transforming utopia into reality and becoming a model in the world [32]. From the garden city, ideal design of spaces serving urban system, to the new city, as propulsive and autonomous development centers that influence the economy of the area [33].

Milton Keynes, created in 1970, interprets this new way of urban development. There is no implementation of a perfectly calculated geometric, but a system of relationships projected to the future, open to progressive and participatory planning.

The Olivetti district in Ivrea Italy and the ENI district in Gela Italy, are relevant examples [33], [34]. The latest generation of new towns has been built according to the urban innovation, which is a new conceptual approach consisting of a vision of the future and real implementation.

The new urban systems, today reveal the strong innovative potential for the interactions among people and physical, technological, financial infrastructures, exchanges and flows of movement. The new settlements are structured around a reformed type of urban welfare, based on different types of services according to the action plan of utilities and technological opportunities.

\section{FROM THEORETICAL SOLUTIONS TO TERRITORIAL IMPLEMENTATIONS}

\subsection{Strategic direction}

This section illustrates the conceptual and disciplinary validity of the relationship between large transport infrastructure and its hinterland, covering the regenerative idea of a productive and directional city, integrated with the neighboring urban centers to support the port.

Therefore, some elements of a territorial regeneration project are proposed that would allow a new industrial scenario, integrating the infrastructural systems with the landscape, urban and architectural ones. It is necessary to design a connected infrastructural network, 
management and service centers, a world trade center and production systems with the use of sustainable energy sources. These elements could represent the cornerstones for a sustainable regeneration of the port urban system in synergy with the existing hinterland.

\subsection{The urban relation in the port area}

The study area concerns the territory near the port of Gioia Tauro. The area is located in the territory of Calabria region, in the south of Italy. In the current situation, three mains urban centers are present: Gioia Tauro, Rosarno and San Ferdinando. The current population is 37,152 and workers are 10,017 (Table 1).

Table 1: Main socio-economic characteristics of the area.

\begin{tabular}{llcc}
\hline Area & \multicolumn{1}{c}{ Town } & $\begin{array}{c}\text { Population } \\
\text { (Inhab.) }\end{array}$ & $\begin{array}{c}\text { Workers } \\
\text { (Number) }\end{array}$ \\
\hline Core area & Gioia Tauro, Rosarno, San Ferdinando & 37.152 & 10.017 \\
\hline \multirow{3}{*}{ First circle } & $\begin{array}{l}\text { Feroleto della Chiesa, Rizziconi, Palmi, } \\
\text { Anoia, Candidoni, Taurianova, Seminara, } \\
\text { Melicucco, Polistena }\end{array}$ & 67.483 & 14.247 \\
& $\begin{array}{l}\text { Laureana di Borrello, San Procopio, Giffone, } \\
\text { Maropati, San Giorgio Morgeto, Cittanova, } \\
\text { Delianuova, Galatro, Serrata, Sinopoli, Scido, } \\
\text { Second circle }\end{array}$ & $\begin{array}{l}\text { Santa Cristina d'Aspromonte, Terranova } \\
\text { Sappo Minulio, Varapodio, Sant'Eufemia } \\
\text { d'Aspromonte, Melicuccà, Cosoleto, }\end{array}$ & \multirow{2}{*}{61.162} \\
& $\begin{array}{l}\text { Cinquefrondi, Oppido Mamertina, San Pietro } \\
\text { di Caridà, Molochio }\end{array}$ & & \\
& Total & 10.003 \\
\hline
\end{tabular}

The area is served by linear and punctual transport infrastructures. Linear infrastructures comprehend TEN-T railway (Tyrrhenian line) belonging to Scandinavian-Mediterranean core network corridor and motorway roads (A2 - Salerno - Reggio Calabria). The reference infrastructure is the port of Gioia Tauro, belonging to TEN-T core network.

Shortly it needs to recall that Gioia Tauro is the first port in Italy for transhipment, in the top five in the Mediterranean Sea and the top fifteen in Europe [11], [35]. The port is connected to the railway line and recently is activated the gateway railway services. The industrial area of Gioia Tauro is located near the terminal area [36]. The main current production regards agri-food and automotive service [37]. Fig. 4 reports a schematic representation of the main transport infrastructures crossing the study area. Note that the industrial area has high development potentialities, in relation to its geomorphological configuration and its geographical position.

\subsection{Ideas and projects for port territorial area}

With reference to the above, some studies and design ideas have been selected, published in magazines and thematic dossiers for the hinterland of the port of Gioia Tauro [38]. Recently a collection of papers referring the area of South Calabria has been published [39]. In the book some interesting ideas and projects are presented. 


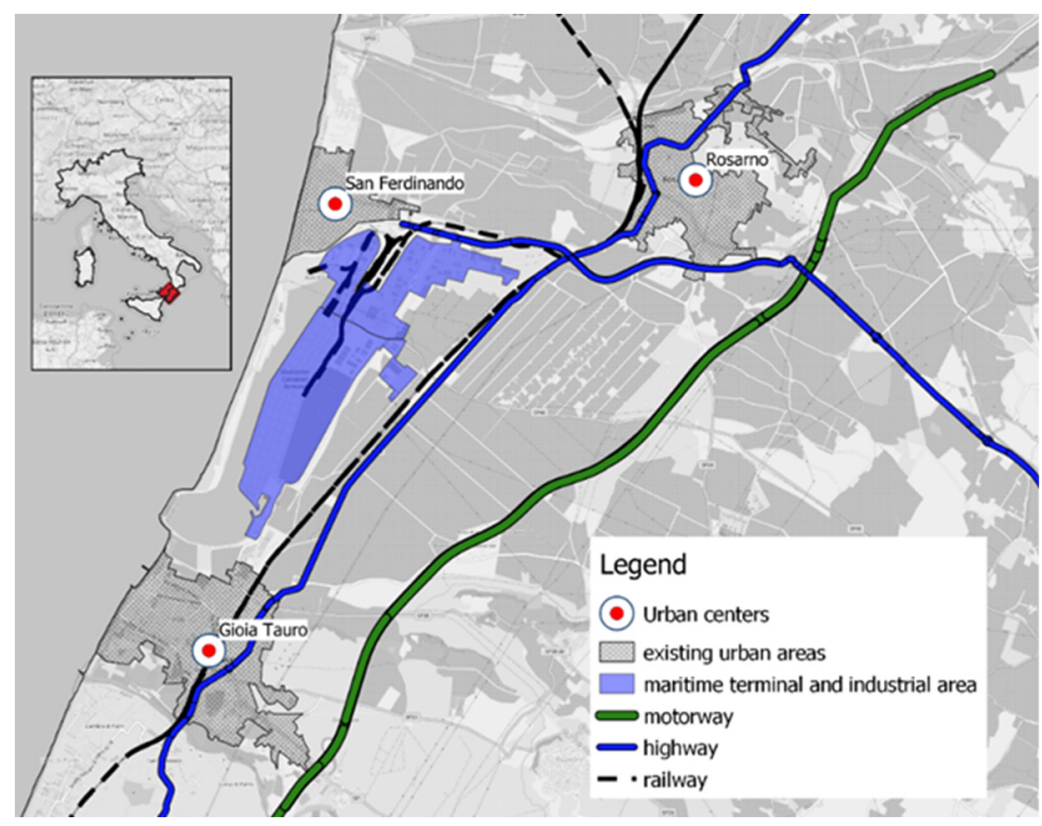

Figure 4: The study area.

The Port produces only for itself; the infrastructure and the territory are not connected. This consideration is the basis of the urbanscape regeneration project, which proposes the port as the new gateway to the sea of Europe [39].

The idea of spatial reconfiguration of the port area of Gioia Tauro with a plan attentive to the infrastructural, economic and environmental sustainability, would offer a possibility of rebirth to the port and the industrial area behind it, currently in a strong state of neglect and decay. The proposals implemented have as a priority the regeneration of the existing which is rethought in line with the principles of the smart city.

The research work on the city of the port highlights the relationship between a large infrastructure and its hinterland, advancing the design idea of a productive and directional city, integrated with urban centers and supporting the port. The lack of infrastructures and services are the main causes of the lack of development. After various analyzes on the context, a vision was envisaged that highlights how the construction of a World Trade Center (WTC) can be the trade union between the city and the port [39].

Also, the study on the infrastructural system and project of a WCT for the port of Gioia Tauro, highlights that among the various problems analyzed, the port infrastructure does not consider its own hinterland and is disconnected from urban centers. The design idea is based on the construction of the WTC as an element of direct communication between the city and the port. A great filter to increase the vegetation and services to citizens and fill the great void existing in the area [39]. The WTC bridge between city and port, would allow the relaunch of the large infrastructure by transforming the current transshipment port into an integrated logistics hub, capable of promoting intermodal transport and creating a new deeper relationship with the surrounding area [39]. 


\section{CONCLUSIONS}

The Gioia Tauro port has been built separated economically and socially from urban centers, even if very near physically. The port is configured as a fence cut out on the territory; transport logistics system, not integrated with neighboring territories. It currently looks like a port infrastructure without the city [39].

The port is now located along a process that leads it to become a third-generation port. The territorial problems are therefore those of resolving the economic and social separation with the nearby urban centers, starting a process that allows transferring part of the added value produced by the port to the residents.

The paper presents the proposed methodology and its implementation. The results obtained are important on two levels. In the first level, the methodology can be applied in other port contexts with the same characteristics of evolution towards third-generation ports. A particularly important reference group is that of the core ports of southern Italy where the Special Economic Zones have been launched, precisely to create added value in goods in transit. At a different level, the results obtained with the application of the methodology to the real case are particularly significant and allow the use of international best practices.

Integrating the existing with regenerative choices of a branch, based on the principles of urban regeneration, is a valid prospect of future development. This is true especially if in the starting scenario there is an infrastructure with high potential, inserted in a territory that is in a state of abandonment and degradation, where empty spaces testify the inefficiencies of the uncontrolled growth. The proposed approach is that of a new smart territory, conceived in the application of the founding principles of the new town and integrated with the principles of sustainable regeneration and smart city. The final goal is to establish a highly significant link between the port, neighboring urban centers and the landscape.

\section{REFERENCES}

[1] UNCTAD, Port marketing and the challenge of the third generation port. Trade and Development Board Committee on Shipping Ad hoc Intergovernment Group of Port Experts, 1994.

[2] Russo, F. \& Musolino, G., Quantitative characteristics for port generations: The Italian case study. International Journal of Transport Development and Integration, 4(2), pp. 103-112, 2020. DOI: 10.2495/TDI-V4-N2-103-112.

[3] Beresford, K.C., Gardner, B.M., Pettit S.J. \& Wooldridge C., The UNCTAD and WORK PORT models of port development: Evolution or revolution? Maritime Policy \& Management, 31(2), pp. 93-107, 2004.

[4] Bichou, K. \& Gray, R., A critical review of conventional terminology for classifying seaports. Transportation Research Part A, 39, pp. 75-92, 2005.

[5] Russo, F. \& Musolino, G., A unifying modelling framework to simulate the spatial economic transport interaction process at urban and national scales. Journal of Transport Geography, 24, pp. 189-197, 2012.

[6] Russo, F. \& Rindone, C., Container maritime transport on an international scale: Data envelopment analysis for transhipment port. WIT Transactions on Ecology and the Environment, vol. 150, WIT Press: Southampton and Boston, pp. 831-846, 2011.

[7] Russo, F., Musolino, G. \& Assumma, V., An integrated procedure to estimate demand flows of maritime container transport at international scale. International Journal of Shipping and Transport Logistics, 6(2), pp. 112-132, 2014.

[8] Russo, F., Musolino, G. \& Assumma, V., Competition between ro-ro and lo-lo services in short sea shipping market: The case of Mediterranean countries. Research in Transportation Business and Management, 19, pp. 27-33, 2016. 
[9] Ben-Akiva, M., Meersman, H. \& Van De Voorde, E. (eds), Freight Transport Modelling, Emerald, 2013.

[10] Tavasszy, L. \& De Jong, G. (eds), Modelling Freight Transport, Elsevier Inc., 2014.

[11] Russo, F. \& Chila', G., Structural factors for a third-generation port: Current state, limits and weaknesses of Gioia Tauro, Italy, in the regional transport plan. WIT Transactions on the Built Environment, vol. 204, WIT Press: Southampton and Boston, accepted for publication, ISSN 1743-3509.

[12] Russo, F., Rindone, C. \& Panuccio, P., European plans for the smart city: From theories and rules to logistics test case. European Planning Studies, 24(9), pp. 17091726, 2016.

[13] Campos Venuti, G. \& Oliva, F. (a cura), Cinquant'anni di urbanistica in Italia. 19421992, Laterza, Bari, 1993.

[14] Salzano, E., Fondamenti di Urbanistica, Laterza, 1998.

[15] EEA, Urban sprawl in Europe - The ignored challenge. EEA Report No.. 10/2006, European Environment Agency, Copenhagen, 2006.

[16] Friedmann, J., Pianificazione e Dominio Pubblico: Dalla Conoscenza All'azione, Edizioni Dedalo: Bari, Italy, 1993.

[17] Jacobs, J., The Death and Life of Great American Cities, Random House: New York, 1961.

[18] Secchi, B., La nuova questione urbana: ambiente, mobilità e disuguaglianza sociali. CRIOS, n. 1, 2011.

[19] Ferlinghetti, R., Paesaggi minimi e spazi urbani. Dintorni, n. 6, pp. 273-296, 2009.

[20] Schilling, J. \& Mallach, A., Cities in transition, vol. 56(4). American Planning Association, 2012.

[21] Celino, A., Concilio G. \& Monno V., Innovazione e pratiche del territorio, Progedit, 2012.

[22] Hitachi-UTokyo Laboratory (H-UTokyo Lab.), The University of Tokyo, Society 5.0. A People-Centric Super-Smart Society, Springer, 2020.

[23] Song, Y., Stead, D. \& de Jong, M., New town development and sustainable transition under urban entrepreneurialism in China. Sustainability, 12(12), p. 5179. DOI: $10.3390 /$ su12125179. 2020.

[24] Lu H., Jong M.D. \& Heuvelhof, E.F., Explaining the variety in smart eco city development in China - What policy network theory can teach us about overcoming barriers in implementation? Journal of Cleaner Production, 196, p. 135e149, 2018.

[25] European Commission, European innovation partnership on smart cities and communities, strategic implementation plan. 2013. https://smart-cities-marketplace. ec.europa.eu/SIP. Accessed on: Feb. 2021.

[26] European Commission. 2014. https://www.interregeurope.eu/fileadmin/user_upload/ tx_tevprojects/library/operation al-implementation-plan-oip-v2_en.pdf. Accessed on: Feb. 2021.

[27] EIP-SCC, Action clusters. 2021. https://eu-smartcities.eu/clusters. Accessed on: Feb. 2021.

[28] EIP-SCC, Projects and sites overview. 2021. https://smart-cities-marketplace. ec.europa.eu/projects-and-sites. Accessed on: Feb. 2021.

[29] UNCTAD, Fourth-generation Port: Technical note. Ports newsletter n. 19, prepared by unCtaD Secretariat, 1999.

[30] Benevolo, L., Storia dell'architettura moderna, Laterza, 2003.

[31] Frampton, K., Storia dell'architettura moderna, Zanichelli, 2006. 
[32] UK, New Towns Act of 1946. https://www.legislation.gov.uk/ukpga/1946/68/pdfs/ ukpga_19460068_en.pdf.

[33] Benevolo, L., Le origini dell'urbanistica moderna, Universale Laterza, Bari, 1989.

[34] Olivetti, A. \& Saibene, A. (a cura di), Città dell'uomo, Edizioni di Comunità, 1960.

[35] Musolino, G. \& Chilà, G., Structural factors for the realization of a third-generation port: Planning general logistics interventions in Gioia Tauro. WIT Transactions on the Built Environment, vol. 204, WIT Press: Southampton and Boston, accepted for publication, ISSN 1743-3509.

[36] Musolino, G., Cartisano, A.G. \& Fortugno, G., Structural factors for the realization of a third-generation port: Planning interventions for mechanical logistics in Gioia Tauro. WIT Transactions on the Built Environment, vol. 204, WIT Press: Southampton and Boston, accepted for publication, ISSN 1743-3509.

[37] Musolino, G. \& Trecozzi, M.R., Structural factors for the realization of a thirdgeneration port: Planning interventions for agri-food logistics in Gioia Tauro. WIT Transactions on the Built Environment, vol. 204, WIT Press: Southampton and Boston, accepted for publication, ISSN 1743-3509.

[38] Russo, F. \& Chila' G., Structural factors for a third-generation port: Actions and measures for Gioia Tauro in the regional transport plan. WIT Transactions on the Built Environment, vol. 204, WIT Press: Southampton and Boston, accepted for publication, ISSN 1743-3509.

[39] Amaro, O. \& Tornatora, M., Idee e Progetti per la Città Metropolitana di Reggio Calabria, Gangemi Editore: Italy, 2016. ISBN 978-88-492-3168-7. 